会長を引き受ける時, ある古い会員からご助言を頂き， 第 1 にデフレで会費収入の維持が困難になる中で学会収 支の健全性の維持改善. 第 2 に利息収入が減っても学会 の魅力は研究教育助成なので, 元本を多少取崩しても研 究教育助成を継続できるようにして後任の会長に引継い で欲しいと言われた。

平成13年が85周年になる事は承知していた. 創立85周 年記念事業は功労ある方々の表彰など行う必要があると 思っていたが募金活動をしようなどとは全く思ってもい なかった。

木滑事務局長さんに基金取崩しのための定款変更の話 をすると後刻文部省の指導官のご意見がもたらされで きれば基金は減らさないようにとのことであった。そこ で思いついたのは現在の東京電力債の利率 $6.7 \%$ が満期 になり買い替えると $1 \%$ 強の利率に下がる，その利率差 の少なくとも数年分を募金で集められないかということ であった。

比較的不況に強い電力に意向を打診する事とし，業界 首脳が集る平成13年 1 月 9 日の日本電気協会新年賀詞 交歓会に出席した。ご担当の故・東京電力株式会社山本
勝副社長(涪)を探したが見つからず，さらに日本電気協会 の方にも頼んで探してもらったが会場内では見つからな かった。あきらめて会場を出た先のエレベーターホール でたまたま電話をされていた目当ての山本さんに奇遇し た．学会の苦境を説明すると協力しましょうといわれ ホッとした。 1 月の理事会に報告し, 創立85周年記念募 金を行う方向が確認された。

検討の結果, 総額 4000 万円の募金規模となり, 総会で 定款を変更し取崩可能基金を設けることとした．創立 85 周年においても学会の魅力と発展のためには, 研究教育 助成, 国際化, 全国大会の活性化が必須である事に変わ りがない. 照明学会創立85周年記念事業委員長として, 学会の魅力を増やすため心から会員の皆様のご支援ご協 力をお願いする次第である。構造不況を打開するには研 究開発に基くベンチャー企業の育成が一つの鍵だとされ ている. 当学会関係者から広く世界に役立つ研究成果が 生れ育って欲しいと願うものである.

（注） 東京電力株式会社山本勝副社長は，平成13年10月 11日に呼吸不全により急逝されました。心よりご冥 福をお祈り申し上げます。

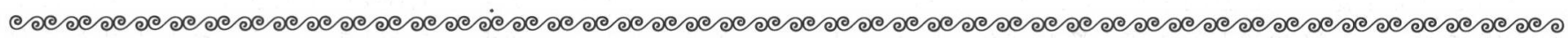
〈学会運営〉

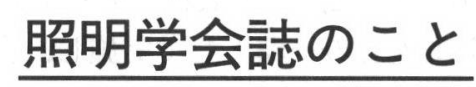

On the Journal of the IEI-Japan

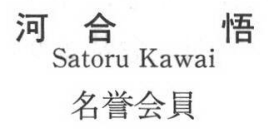

名誉会員

悟

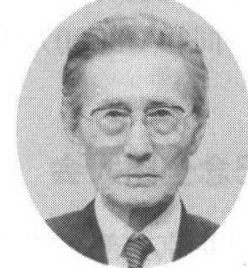

1926年生. 1953年慶應 義塾大学大学院卒. 1980年中京大学文学部 心理学科教授. 1997年 運輸大臣表彰受賞. 現 在, 中京大学名誉教授.

\title{
\キーワード：学会誌, 編集
}

私が初めて学会誌の編集委員になったのは, 現日本大 学名誉教授の室井德雄氏と故・寺村修氏が編集理事をさ れていた昭和39年だったと思います。それ以来，なぜそ うなったのかは判りませんが, 途中多少空白があります が，平成 7 年頃までの約 30 年間，おしまいの頃はまるで “ぬし”みたいに学会誌編集に関わっていました，その 間に学会誌の編集, 発行などに起こったことを, 思い付 くまま書いてみます。記録などを確認しないまま書きま すので, 事実と違っていることがあるかも知れませんが, ご容政下さい.

私が新米だった当事の学会誌のサイズは現在のサイズ (A 4 版) より小さいB 5 版でした。 そして, 論文と一 般記事とを, 現在のように別冊にしないで, 同じ版にごっ ちゃに揭載していました. 論文投稿数も少なく，一件も ない時や，多い時でもせいぜい二件どまりだったと記憶 しています. 編集委員会の委員数も 10 人弱で, 昔の電気 ビルの小さい部屋で会議をしていたような気がしていま す。一般記事はどうやって集めていたかは，末席にちょ こんといただけだったので，全く記憶に有りません。特
集号なんて云うのはなかったと思っています.

いつからかは知りませんが, 当事よりずっと以前から 昭和 60 年頃事務局の小沢重雄課長が定年退職されるま では, 同氏が学会誌の編集から発行までの全ての仕事を 責任を持って処理されていたので, 編集委員会は論文の 查読と一般記事を集めることだけが仕事でした。予算を 見計らって, この記事は次号に回そうと云うようなこと から, 全ての記事の言葉づかい, 使用漢字などの統一, 図面の整備, トレースの発注，記事の割付け，印刷屋関 係の全て（校正も含む）などなど，何から何まで同氏が 一人でこなして居られました。

私が編集理事をお引き受けしたのが小沢氏の定年直前 でしたので，同氏の退職後をどうするかを考えざるを得 ませんでしたが，その時つくづく同氏が大変な仕事, 数 人分の仕事，を一人でこなしていたと云う事を思い知り ました。

昭和54年, 当事日立の山根幹也氏が編集委員会の委員 長だった時だと思いますが，その時，論文だけをまとめ て論文号として年 2 回，一般号を年 9 回，年報を 1 回と 
すること，及び，本のサイズをA 4 にすることが決まり ました。また，その時，表紙のデザインを山縣信輔氏に 委嘱して新しくしました。

その頃，論文投稿数が以前より多くなって来たのでこ のように決まったのですが，論文の投稿数には波があっ て多い時は多いのですが，まるで投稿が無いような時も しばしばでしたので，論文が集まらなかったらどうしよ うと云うことを，相当心配されました。

話を変えて，年報についてちよっと述べます．年報に 関しては編集委員会とは全く別の照明発達調査委員会と 云うのがあって，その委員会が扱っていたと記憶してい ますが，年報の内容がいまいち何とかならないかと云う 声が絶えずあって，これをいかに改正すべきかを検討す る委員会ができたりした事もありましたが，内容に関し ては，現在に至るまで大して変わっていません．編集方 法に関しては，マイナ一な変化が絶えずあって，現在の ような形になっています。私が編集委員長をしていた時 にも，当事，年報関係の委員長であった（委員会名は何 であったか覚えていません）故・寺村修氏に色々と，結 構しつこく，折衝した記憶がありますが，その内容は全 く覚えていません.

話は戻りますが，その後，論文号が年 4 号となって現 在に至っています，当事の委員会では，論文号を年 4 号 にすると，学会誌が月刊誌である限り，一般記事にしわ 寄せがあると云う理由で反对する委員が相当数いました が，8月号を一般号とし，年報号を別冊にする事で決着 したと記憶しています。

私の専門は心理学ですが, 心理学会訫は全て論文だけ です。そもそも学会は会員が論文を発表する場として作 られているものであり, 従って，学会と称する限りは， 基本的には，学会誌発行と，年一回の全国大会と云うお 祭をすることが，学会がなすべき仕事の全部であると 思っています。ですから, 照明学会誌でも, 心理学会と は違う色々な事情がある事は判りますが，一般記事は投 稿論文数の足りない分の埋め草であるとどうしても思っ てしまうのです。これは次の事にも係わっています。 照明学会では，一般会員の会費全部を学会誌発行の費 用に当て，電力会社などの大スポンサーが事務所の家賃 を含めた事務にかかる費用などを持ってくれているのが 現状です，要するに，学会誌発行に当てる事ができる費 用には限度があります。掲載すべき論分数が増えても一 般記事を減らさないなら，学会誌の総ページ数が増え， 当然発行費用も増えます。それまでも，使っていた費用 は限度一杯だったのですから，当然赤字となります。そ こで論文掲載料を超大幅に值上げしてこれをまかなって いるのが現状です。と云うよりは, 論文号発行に要する 費用のほとんどを掲載料でまかなう什掛けで，こうすれ ば掲載論文数がいかに増えようが，一論文のページ数が
いかに多かろうが，破綻を来さないと云うわけです。私 はこのやり方は余り芳しいとは思いません.何となれば， これは論文を投稿することを主たる目的で会員になって いる最も本来的な会員が最も割を食っていることになっ ているからです。

先に述べたごとく，私が編集委員長であった時（昭和 59年)は，小沢課長の定年間際でしたので，同氏退職後， 学会誌編集をどういう形でしたらよいかを，私と同時に 編集理事に就任した河本康太郎氏と共に種々検討し，小 沢氏がしていた仕事の主要な部分を外注することにし て，小沢氏の後任には若い女性を当て，原稿の保管，郵 送，種々の連絡程度の仕事だけを残す。外注の費用は雨 者の給料の差額程度を目処に外注先を探すという方針で 各方面に当たって見ようということにしましたところ が，採用人事で当事の事務局長と意見が合わず，若い女 性採用は実現しませんでした。実は，女性でなくても初 任給は変わらないので当面は同じです，女性はすぐ辞女 てしまうからだめだと云うのが局長の主張で，すぐ辞め るから次々安い給料ですむと云うのが私の考えでしたか ら，局長の主㲀の方が正当です。

理事の任期終了後も，二人で“学会誌編集のあり方検 討委員会”と云うのを設けて，上記方針の実現に努めま しな。しかし，信頼できる編集をしてくれると思われる 所は，金額の点でとても手が出ず，金額ではまあまあの 所は今いち信頼できなかったり，こちらに相当量の仕事 が残ったりでこれもだめ.当事印刷を頼んでいた奥村印 刷は単なる印刷屋なので編集の能力はないが，小沢氏に 適当な報酬を支払って編集の指導を受けるという形で試 しにしばらく引き受けてもらったけれど，これもうまく いかず，結局，現在の丸井工文社と契約することになり ました。契約内容は当時と現在とではだいぶ変わってい ます。

英文誌のことも書いた方が良いのでしょうが，今回は 止めることにします。

いつも気になっていることがあるので，この紙面を借 りて，ちょっと触れさせてもらいます。

以前少人数でやっていた編集の仕事が，いつの日か 段々膨れて現在は 100 名弱（80数名）の方々が編集に係 わっています。全てボランティアです。昔は種々の委員 会に出席している量に応じて，年末に相当高価なものが 贈られていました。その後，それは廃止され，委員会一 回出席毎に500円わたすことがしばらく続き，それも廃 止され，現在では全くの無料です．私は無料であること は良いことだと思っています。けれども，ただだからと 云って好い気になって委員会や委員数を増やすのは良く 有りません，何事も適正值が有ります。編集委員会の仕 事は編集の仕事のうちの記事を揃えることだけです．何 名が適正值かは即答できませんが，例えば英文誌は内容 


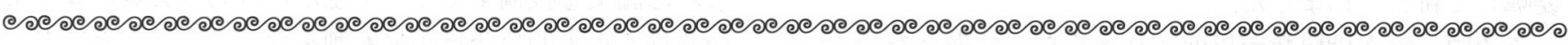
〈学会運営〉

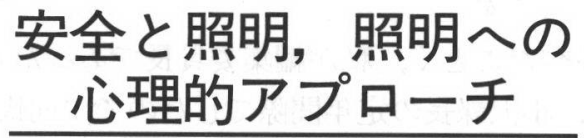

Lighting for Safety ; a Psychological Approach to Lighting

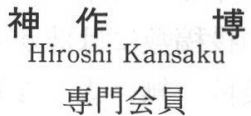

専門会員

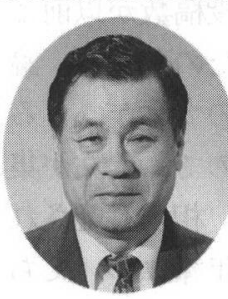

1934年生，1957年千葉 大学文理学部心理学専 攻卒. 現在, 中京大学 心理学部教授 ·同大学 院文学研究科長. 1987 医博, 著書「航空照明」, 「ライティングハンド ブック」(共同執筆) 等.

\section{1.はじめに}

筆者が照明学会へ入会したのは昭和 35 年のことであ ク, 当時, 航空標識の色の研究でご指導をいただいてい た川上元郎先生（現・名誉会員）のお勧めであった。

この頃の筆者の関心は航空安全標識・航空灯火の見え 方およびそれを左右する環境の照明・色彩についてで あった。

\section{2. 自然環境の照明・色彩の測定}

昭和37年，航空標識などの背景となる自然環境の測 光·測色の研究で, 千歳空港の周囲の環境色の測定を行っ たが，ハンディな測色器も入手できず，マンセル色票帳 を用いての視感測定であった。また，航空機標識や航空 灯火の視認性の研究に必要とされる環境内の輝度・照度, 色温度などの測定を行ったが，これまたハンディな測光 器が市場には存在せず，測定に際しては非常な工夫を要 し苦労した. 川上先生と測色器メーカーを訪問し, 製品 化を留願したりしたのもなつかしい思い出である.

この頃, 川上先生のご発想で長岡高専の池守先生, 新 潟大学の安藤先生達と共同で日本における天空光の輝 度・色温度測定が始まった。筆者は立川市における測定 を担当し，同時に小型のジェット機に搭乗し，北海道， 関東, 東海・中部各地方の地上から $10000 \mathrm{~m}$ 上空までの各 高度における測定を担当した（この測定においても測定 器に関する苦労は同様であった)。

この活動は, 後年, 学会の昼光標準確立調查研究委員 会の開設を促し，わが国の昼光標準確立の礎となり，そ の後のこの種の研究の前身となっていったと思われる.

これらと平行して筆者は海難救助用のダイマーカー

（海染剤）の視認性向上の検討の必要から海の色の測定 もへリコプターの機上より行った。測色機器の不便さは 相変わらずの状態であり, 今日の測定機器類の精密化・ 小型化などをみると隔世の感がある.

当時，鉄道信号の見え方向上に資する野外の環境内の 物体の測光・測色を行っておられた，故・正木光先生に いろいろとご指導も頂いた。

\section{3. 航空照明の研究}

昭和 30 年代の後半に民間航空機の大事故が相次いで 発生し，それらの事故調査の一部に従事した。 なかでも カナダ航空機の羽田空港着陸失敗事故では，霧の中での 飛行場の航空諸灯火の視認の可否が原因究明上大きな問 題となった。このことに端を発し，それ以後，当時の運 輸省（現国土交通省）航空局などよりの「航空灯火の見 え方」に関する研究委託が当学会へと出され, 以後現在 にまで及んでいる。これら一連の研究は, 安全上はもち ろんのこと, 国際規格設定についても当学会の主要な社 会貢献の活動の一つとなっている. 当初は当学会関係者 が航空灯火や航空機の運行などに不慣れであったため か, 昭和52年頃まで筆者もこの一連の研究のメンバーに 加えていただいた. その頃のエピソードを二つ.一つは, 羽田空港での滑走路改修のチャンスを狙い，平行する滑 走路への着陸機の動向を常に気にしつつ，滑走路末端に 電気工事用の柱上作業車を着陸機の操縦席の高さに模し て設置し, 灯火の見え方実験を実施中あわやニアミスと いうことをも経験したこともあった。また，別のときに は，たまにしかえられない実験チャンスを有効に生かす べく欲張りすぎて, 灯火輝度などの変化段階を多く組み すぎ,ついに夜明けにまで至ってしまったこともあった。

昭和45年の夏には, 飛行場のある場所で唯一夏に霧の 発生する北海道釧路空港に赴き, 航空灯火の見え方の実 験を行った。濃い霧の中でプリッチャード輝度計が湿気 のため不正確となり，見え方結果との対応に不一致が生 じた。人間の判断の強みが改めて実感された一幕であっ た. 滞在中, 宿舎の隣で毎朝催される魚市場で, 脚がも げ割安になった毛ガニを沢山買い込み, 関係者一同腹一 杯食べた記憶は今でも忘れられず，なつかしい。

\section{4. 照明と心理的実験}

当時は心理学を専門とする学会員が極めて少なく，照 明の人間心理に及ぼす影響についての実験結果が不足が ちであった。

照明の量と見え方についての研究は Luckiesh らの研 究に代表される研究が有名であり，また印東・河合両先 